\title{
Constructed Wetland for Wastewater Treatment and Reuse: A Case Study of Developing Country
}

\author{
Atif Mustafa
}

\begin{abstract}
Treatment performance of a pilot-scale constructed wetland $(\mathrm{CW})$ commissioned in a developing country was evaluated for removal efficiency of biochemical oxygen demand (BOD), chemical oxygen demand (COD), total suspended solids (TSS), ammonia-nitrogen $\left(\mathrm{NH}_{4}-\mathrm{N}\right)$, ortho-phosphate $\left(\mathrm{PO}_{4}-\mathrm{P}\right)$, total coliforms (TC) and faecal coliforms (FC) from pretreated domestic wastewater. Monitoring of wetland influent and effluent was carried out for a period of 8 months. Treatment effectiveness was evaluated which indicated good mean removal efficiencies; BOD $(50 \%)$, COD (44\%), TSS (78\%), $\mathrm{NH}_{4}-\mathrm{N}(49 \%), \mathrm{PO}_{4}-\mathrm{P}(52 \%)$, TC (93\%) and FC (98\%).

The studied constructed wetland reduced concentrations of all contaminants present in the pretreated wastewater. The performance of contaminant removal varied throughout the monitoring period. The treated effluent from the constructed wetland can be reused for landscape irrigation. Few samples of BOD and TSS were within the US EPA reuse limits which shows that the constructed wetland can effectively treat the wastewater and fulfill the reuse limits occasionally. Faecal coliforms were not fully removed but the limits for reuse were achieved occasionally. For developing countries like Pakistan with limited technological advancement and energy problems, constructed wetlands which have a zero or very low energy requirement can be used in the treatment trains.
\end{abstract}

Index Terms-Constructed wetland, developing countries, reuse, treatment.

\section{INTRODUCTION}

Conventional wastewater treatment systems comprising of energy intensive and mechanized treatment components require heavy investment and entail high operating costs. Experience has shown that existing wastewater treatment systems in most of the developing countries which were built through funding by international donor agencies failed to treat wastewater adequately. Reasons for inadequate treatment include high maintenance costs, lack of local expertise and poor governance. Compared to conventional treatment systems, constructed wetlands are low cost, easily operated and maintained, and have a strong prospective for application in developing countries. Constructed wetlands are accepted as a reliable wastewater treatment technology and represent an appropriate solution for the treatment of many wastewater types [1].

Comparing with conventional wastewater treatment

Manuscript received December 07, 2012; revised January 28, 2013. This work was financially supported by NED University of Engineering and Technology.

A. Mustafa is with the Environmental Engineering Department, NED University of Engineering and Technology, Karachi-75270, Pakistan (e-mail: atifm@neduet.edu.pk, atifmenv11@yahoo.com). systems constructed wetlands have a higher rate of biological activity which enables conversion of many of the pollutants that are contained in the wastewater into non-toxic by products or essential nutrients that can be reused for additional biological activity [2]. They have been used for secondary and also in some cases for tertiary level treatment and reuse. For example, they have been successfully used to treat wastewater to meet standards developed by regulatory bodies.

Globally, most of the developing countries are geographically located in those parts of the world that are or will face water shortages in the near future. Moreover, the existing water sources are contaminated because untreated sewage and industrial wastewater is discharged into surface waters resulting in impairment of water quality. This practice in addition to contaminating the drinking water sources also negatively impacts irrigation, fish production or recreation [3]. Water pollution is one of the main menaces to public health in developing countries. Therefore, it is important to protect the existing water sources by treating wastewater discharges from human activities and to reuse wastewater to combat water scarcity.

It is important to adopt those technologies for wastewater treatment which can adequately treat wastewater in the long run i.e. sustainable technologies. Incorporation of high-tech wastewater treatment systems seems irrelevant as it is techno-economically infeasible as discussed above. The developed countries are striving to control micropollutants while developing countries are still struggling to control macropollutants (organic material, nutrients and pathogens). Constructed wetlands have shown to successfully control organic material, nutrients and pathogens. [4] reported that constructed wetland technology is a viable option that not only reduces nutrients but it performs the function of disinfection, rendering the treated wastewater a resource to irrigate crops, playing arenas, gardens or golf courses. Constructed wetlands are achieving prominence as an active and low cost alternative for treatment of wastewater in both the developed and developing world.

The rationale of this paper is to advance the use of constructed wetland technology for wastewater treatment and reuse in developing countries like Pakistan. The overall goal of this paper is to assess the performance of a pilot-scale constructed wetland through studying its treatment performance. It will provide information on the role of these systems for wastewater treatment and reuse. Detailed monitoring of the wetland water quality was carried out for a pilot-scale wetland that was designed to treat domestic and institutional wastewater. The specific objectives are:

1) To evaluate the performance of constructed wetland; and 
2) To assess the application of constructed wetland for reuse.

\section{MethodS}

\section{A. Experimental Site}

The constructed wetland (CW) treatment system is situated in Karachi, NED University of Engineering \& Technology, at a longitude $25^{\circ} 56^{\prime} 8^{\prime \prime} \mathrm{N}$ and latitude $67^{\circ} 06^{\prime} 44^{\prime \prime} \mathrm{E}$. The maximum and minimum temperatures during the study period were $36^{\circ} \mathrm{C}$ and $20^{\circ} \mathrm{C}$, respectively. NED wastewater treatment plant (WWTP) treats wastewater from campus and staff colony. The wastewater contains domestic sewage and low flows from laboratories of various university departments. The primary treatment consist of a settling tank, after that the wastewater is transferred to an aeration tank and then to a secondary settling tank. The main objective to construct the wetland at the WWTP site is to evaluate the performance of simple and low-cost wastewater treatment technology.

\section{B. Constructed Wetland Design}

The effluent entering the $\mathrm{CW}$ system (cell) comes from a WWTP which treats domestic and institutional wastewater. The key features of this $\mathrm{CW}$ are horizontal surface flow (HSF). The HSF CW was selected as this kind of system does not have the clogging problem. The constructed wetland is designed as a plug flow reactor and length to width ratio (L: W) is $4: 1$. The cell design consists of a rectangular bed, bordered with masonry work of $0.25 \mathrm{~m}$ wall and concrete based floor to protect seepage of wastewater. The cell is 0.30 $\mathrm{m}$ above and $0.30 \mathrm{~m}$ below the ground, so no external water enters into the cell from the natural ground surface. The system is designed for a flow of $1 \mathrm{~m}^{3} / \mathrm{d}$.

The design of this pilot-scale constructed wetland consists of a bed that is rectangular in shape and is planted with common wetland plant (Phragmites karka). Pre-treated wastewater is fed in the storage tank placed at the influent end of the wetland; the influent entering the $\mathrm{CW}$ is controlled manually by adjusting the valve attached to the inlet pipe. The flow between inlet and outlet is by gravity. PVC pipes at the inlet and outlet zone are slotted to distribute and collect the wastewater. This slotting method reduces short circuiting in the cell and the whole bed is utilized to treat the wastewater. The treated wastewater from the outlet zone is collected is a small ditch walled with masonry bricks. The inlet pipe has a diameter of $5 \mathrm{~cm}$ while outlet pipe diameter is $10 \mathrm{~cm}$ (Fig. 1). The soil used for wetland bed was first checked that no roots of any other plants are present. Then the cell was half filled with the soil in such a way that wastewater will flow towards the effluent end by making inclination of 5 degrees. The bed was filled with water to settle the soil and facilitate the growth of macrophytes. The main features of the constructed wetland at NED University are presented in Table I while Fig. 1 shows the layout of $\mathrm{CW}$ added to the treatment train.

Young plants of Phragmites karka were collected from the campus surroundings in late May, 2010. The plants were transplanted the same day in the bed at a density of four plants per square meter. The cell was filled with fresh water so that the macrophytes adapt to the new environment. Later on, the cell of $\mathrm{CW}$ was loaded with settled domestic wastewater from the campus and staff colony. Sampling scheme was initiated after an acclimatisation period of 6 weeks.

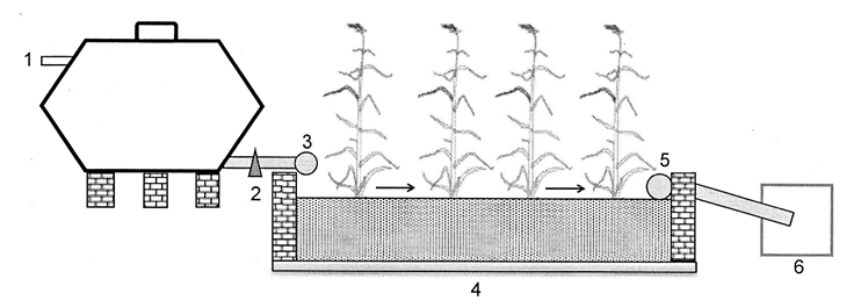

Fig. 1. Pilot scale constructed wetland layout: (1) secondary wastewater effluent from wastewater treatment plant to storage tank, (2) control valve, (3) inlet pipe, (4) constructed wetland (5) outlet pipe, (6) water level control box.

TABLE I: MAIN FEATURES OF THE CONSTRUCTED WETLAND

\begin{tabular}{llc}
\hline \hline Parameter & Unit & Value \\
\hline Length & metre & 6 \\
Width & metre & 1.5 \\
Height & metre & 0.6 \\
Surface area & Square metre & 9 \\
Hydraulic retention time & days & 4 \\
Flow & Cubic metre per day & 1 \\
Vegetation & Per square metre & 4 plants \\
\hline \hline
\end{tabular}

\section{Sampling Methods}

For wastewater analysis, grab samples were collected in plastic bottles previously washed and rinsed with distilled water. Samples were collected after every two weeks from the inlet and outlet of the CW. Liquid samples were tested for $\mathrm{pH}$, total dissolved solids (TDS), total suspended solids (TSS), 5 days biochemical oxygen demand $\left(\mathrm{BOD}_{5}\right)$ at $20^{\circ} \mathrm{C}$, chemical oxygen demand (COD), ammonia nitrogen $\left(\mathrm{NH}_{4}-\mathrm{N}\right)$ ortho-phosphate $\left(\mathrm{PO}_{4}-\mathrm{P}\right)$, temperature, dissolved oxygen (DO), faecal coliforms (FC), total coliforms (TC) using American Public Health Association standards methods [5]. All samples were analysed in the laboratory of environmental engineering department.

\section{RESUlts AND DisCUSSION}

During the eight months monitoring period which started in the month of September, 2010 and continued till late April 2011, samples were collected from the $\mathrm{CW}$ system and analysed for each of the various physical, chemical and microbiological parameters. Table II presents the average inlet and outlet concentrations of each monitored parameter. The mean $\mathrm{pH}$ value increased slightly between influent and effluent; from 7.8 to 7.9. [2] reported that vegetated free-water surface wetlands produce effluent with $\mathrm{pH}$ just above neutrality.

\section{A. Organic Matter}

Fig. 2 describes the variation of the organic pollutants in both influent and effluent concentrations during the monitoring period. The inlet BOD concentration ranged between $32.5-110 \mathrm{mg} / \mathrm{L}$ while that of the outlet ranged between $13-71 \mathrm{mg} / \mathrm{L}$ (Fig. 2a). The mean inflow value for BOD was $68.6 \pm 23.6 \mathrm{mg} / \mathrm{L}$. The average reduction in BOD 
concentrations over the monitoring period was $50 \%$ with mean effluent $\mathrm{BOD}_{5}$ concentration of $34 \pm 15.5 \mathrm{mg} / \mathrm{L}$. The inlet COD concentration ranged between $56-225 \mathrm{mg} / \mathrm{L}$ while that of the outlet ranged between $35-95 \mathrm{mg} / \mathrm{L}$ (Fig. 2b). The mean COD concentration decreased from $122.9 \pm 50.7$ to $68.3 \pm 20.7 \mathrm{mg} / \mathrm{L}$, achieving an average reduction of $44 \%$. The variability in influent BOD and COD concentration was because of intermittent power failure resulting in closure of wastewater treatment plant. However, performance of $\mathrm{CW}$ shows that the system has a good buffer capacity and is able to tolerate organic shock loads. There was a decrease in inlet and outlet $\mathrm{BOD}_{5} / \mathrm{COD}$ ratio from 0.55 to 0.27 showing that organic matter liable to biological degradation was removed by the CW system. Forty eight percent of effluent BOD concentrations except for the initial months and some in later were below the threshold of $30 \mathrm{mg} / \mathrm{L}$ as set by US EPA for wastewater reuse.

\begin{tabular}{clccccc}
\multicolumn{2}{c}{ TABLE II: WATER QUALITY VARIABLES MEAN \pm (STANDARD DEVIATION) FOR THE CONSTRUCTED WETLAND } \\
\hline \hline S. No. & \multicolumn{1}{c}{ Variables } & Unit & $\mathrm{n}$ & Inlet & Outlet & Reduction $(\%)$ \\
\hline 1 & Biochemical oxygen demand & $\mathrm{mg} / \mathrm{L}$ & 16 & $68.6 \pm 23.6$ & $34.0 \pm 15.5$ & 50 \\
2 & Chemical oxygen demand & $\mathrm{mg} / \mathrm{L}$ & 16 & $122.9 \pm 50.7$ & $68.3 \pm 20.7$ & 44 \\
3 & Total suspended solids & $\mathrm{mg} / \mathrm{L}$ & 16 & $201.4 \pm 93.2$ & $45 \pm 26.3$ & 78 \\
4 & Ammonia-nitrogen & $\mathrm{mg} / \mathrm{L}$ & 16 & $19.2 \pm 4.8$ & $9.7 \pm 4.6$ & 49 \\
5 & Ortho-phosphate & $\mathrm{mg} / \mathrm{L}$ & 16 & $7.6 \pm 1.9$ & $3.7 \pm 2.3$ & 52 \\
6 & Total coliforms & Counts/100mL & 12 & $2.1 \times 10^{6}$ & $8 \times 103$ & 93 \\
7 & Faecal coliforms & Counts/100mL & 12 & $1.1 \times 10^{6}$ & $3 \times 103$ & 98 \\
8 & pH & - & 16 & $7.8 \pm 0.7$ & $7.9 \pm 0.4$ & - \\
9 & Dissolved oxygen & $\mathrm{mg} / \mathrm{L}$ & 16 & $1.7 \pm 0.6$ & $4.5 \pm 1.2$ & - \\
\hline \hline
\end{tabular}

(a)

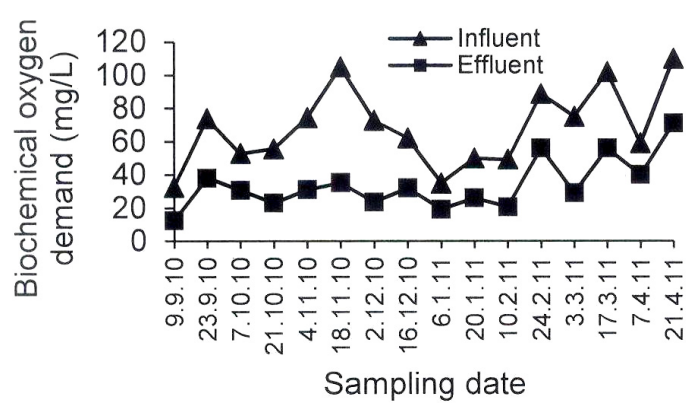

(b)

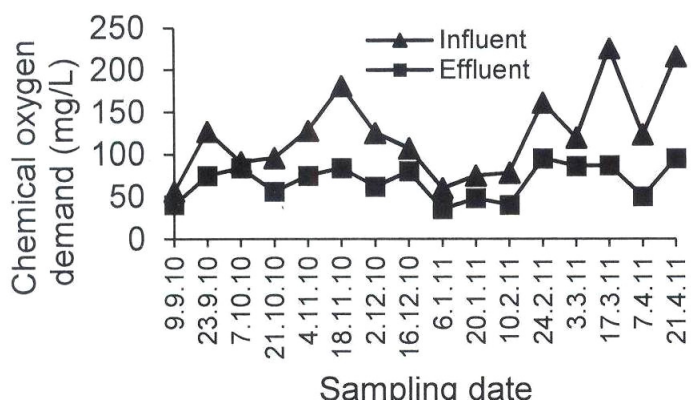

Fig. 2. BOD (a) and COD (b) influent and effluent concentrations for the wetland system at NED University.

\section{A. Total Suspended Solids}

The mean influent and effluent TSS values were 201.4 $\pm 50.7 \mathrm{mg} / \mathrm{L}$ and $45.0 \pm 26.3 \mathrm{mg} / \mathrm{L}$, respectively. TSS at the inlet varied between $95-350 \mathrm{mg} / \mathrm{L}$ (Fig. 3) and at the outlet between 13 - $92 \mathrm{mg} / \mathrm{L}$ (Fig. 3). Solids removal efficiency ranged from $73 \%$ to $86 \%$ with an average reduction of $78 \%$. Fig. 3 shows variations in influent and effluent TSS. The figure shows that influent TSS fluctuated while the effluent TSS values were consistently low except for the initial two months. Suspended matter is removed primarily through the mechanism of interception and settling [2]. Thirty eight percent of effluent SS concentrations except for the initial months and some in later were below the threshold of 30 $\mathrm{mg} / \mathrm{L}$ as set by US EPA for wastewater reuse.

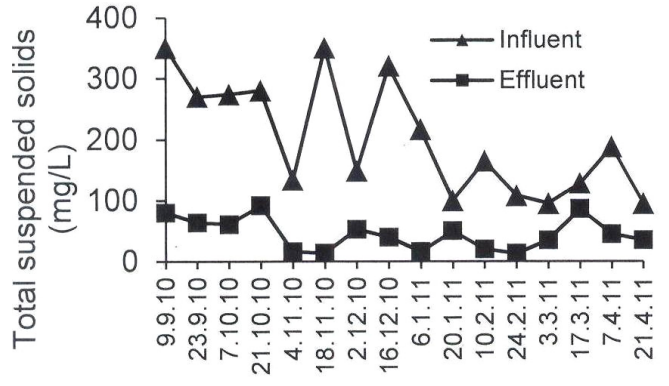

Sampling date

Fig. 3. TSS influent and effluent concentrations for the wetland system at NED University.

Suspended solids are removed by physical processes such as sedimentation, aggregation and interception. The size and number of wetland cells also influence the removal of SS. Greater number of cells will facilitate greater SS removal. The CW consists of a single cell and the pretreatment of the wastewater was disrupted intermittently because of power failure. This may be the reason of high TSS concentrations on some occasions.

\section{B. Nutrients}

The inlet $\mathrm{NH}_{4}-\mathrm{N}$ concentration ranged between $10-29 \mathrm{mg} / \mathrm{L}$ (Fig. 4a) while that of the outlet ranged between $3-18 \mathrm{mg} / \mathrm{L}$ (Fig. 4a) with mean values of $19.2 \pm 4.8 \mathrm{mg} / \mathrm{L}$ and $9.7 \pm 4.6$ $\mathrm{mg} / \mathrm{L}$ at the inlet and outlet, respectively (Table II). A number of processes transfer compounds from one point to another in wetlands like ammonification, nitrification, denitrification, decomposition [2]. Controlling and decreasing ammonia concentrations is a key consideration in the design of wetland treatment systems because ammonia is the principal form of nitrogen in wastewater and has the potential to degrade the environment.

The reduction in ammonia-nitrogen concentration for this study was $49 \%$. Reference [6] conducted a study on the performance of a full-scale constructed wetland system for sewage treatment in China and found a $40.6 \%$ reduction in 
ammonia-nitrogen concentration while for this study; ammonia-nitrogen removal efficiencies observed were quite low. This may be due to the development of conditions (e.g. anaerobic) that may not be fully supporting the microbially mediated nitrification process which transforms ammonia-nitrogen to nitrate-nitrogen.

(a)

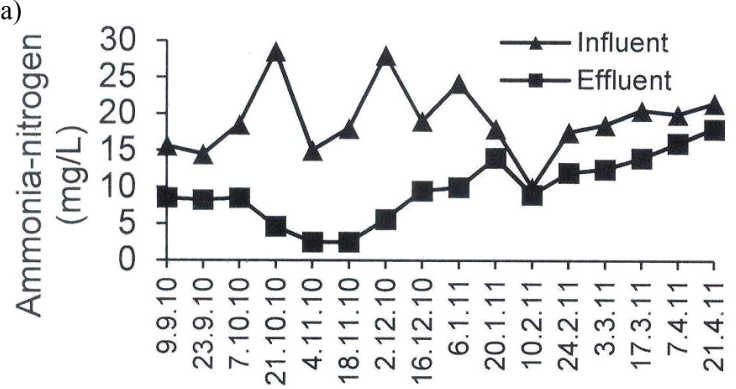

(b)

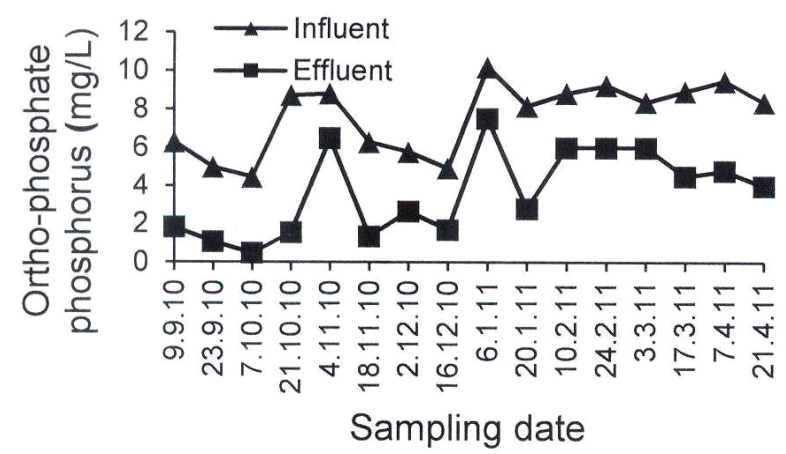

Fig. 4. $\mathrm{NH}_{4}-\mathrm{N}$ (a) and $\mathrm{PO}_{4}-\mathrm{P}$ (b) influent and effluent concentrations for the wetland system at NED University.

The inlet $\mathrm{PO}_{4}-\mathrm{P}$ concentration ranged between 4.5-10.2 $\mathrm{mg} / \mathrm{L}$ (Fig. 4b) while that of the outlet ranged between 0.5-7.5 $\mathrm{mg} / \mathrm{L}$ (Fig. 4b). Average reduction in ortho-phosphate concentration over the monitoring period is $52 \%$ as indicated in Table II. Phosphorus removal processes in wetlands include sorption, precipitation, biomass storage and accretion. Sorption and biomass building have limited phosphorus retention capacities as compared to newly created refractory residual [2]. Characteristic of soil has an important influence on the magnitude of phosphorus removal. Various factors including particle size distribution influence the ability of wetland soil to hold phosphorus. The reason for lower phosphorus removal is the lower binding capability of wetland soil.

\section{Indicator Bacteria}

The $\mathrm{CW}$ reduced both total and faecal coliforms. The average removals of the analysed indicator bacteria (total coliforms and faecal coliforms) were in the range 93-99\%, showing a high efficiency of the constructed wetland system in removing the pathogens. The concentrations of total coliforms and faecal in the constructed wetlands is presented in Table II. Average concentrations of total coliforms and faecal coliforms in the influent were $2.1 \times 10^{6}$ counts $/ 100 \mathrm{~mL}$ and $1.1 \times 10^{6}$ counts $/ 100 \mathrm{~mL}$, respectively. Average effluent concentrations were $8.0 \times 10^{3}$ and $3.0 \times 10^{2}$ for TC and FC, respectively. Natural treatment technologies have the potential to reduce pathogen because of natural die-off and hostile environmental conditions [2].

\section{Suitability of Constructed Wetland Effluent for Reuse}

Table III shows the number of samples that met the US EPA reuse limits [7]. CW effluent occasionally met the reuse limits for unrestricted urban reuse. This shows that if the $\mathrm{CW}$ is properly managed, effluent can be reused for landscape irrigation. Table IV represents the salinity (ECw) of effluent was found to be $1.1 \mathrm{dS} / \mathrm{m}$ which shows a slight to moderate degree of restriction on use for landscape irrigation while total dissolved solids (TDS) value was $642.8 \mathrm{mg} / \mathrm{L}$ also indicating slight to moderate degree of restriction. TDS below $500 \mathrm{mg} / \mathrm{L}$ has generally no negative effects. TDS between 500 and $1000 \mathrm{mg} / \mathrm{L}$ in irrigation water can affect sensitive plants which are normally not used for landscaping. Moreover, the wetland plants can be harvested and used for various beneficial purposes.

TABLE III: Number (Percentage) OF SAMPles MEeting US EPA Reuse GUIDELINES.

\begin{tabular}{lccc}
\hline \hline Variables & Units & CW effluent & US EPA Limits \\
\hline $\mathrm{pH}$ & $\mathrm{mg} / \mathrm{L}$ & $16(100)$ & $6-9$ \\
$\mathrm{BOD}$ & $\mathrm{mg} / \mathrm{L}$ & $7(44)$ & 30 \\
$\mathrm{TSS}$ & $\mathrm{mg} / \mathrm{L}$ & $5(31)$ & 30 \\
Faecal Coliforms & $\mathrm{CFU} / 100 \mathrm{~mL}$ & $3(19)$ & 200 \\
\hline \hline
\end{tabular}

TABLE IV: DEGREE OF RESTRICTION FOR LANDSCAPE IRRIGATION.

\begin{tabular}{|c|c|c|c|c|c|}
\hline \multirow{2}{*}{ Parameters } & \multirow{2}{*}{ Unit } & \multicolumn{3}{|c|}{ Degree of Restriction on Use } & \multirow{2}{*}{$\begin{array}{l}\text { Results of } \\
\text { this Study }\end{array}$} \\
\hline & & None & Slight to moderate & Severe & \\
\hline $\mathrm{ECw}$ & $\mathrm{dS} / \mathrm{m}$ & $<0.7$ & $0.7-3$ & $>3$ & 1.1 \\
\hline TDS & $\mathrm{mg} / \mathrm{L}$ & $<450$ & $450-2000$ & $>2000$ & 642.8 \\
\hline
\end{tabular}

\section{CONCLUSION}

The monitoring of horizontal flow constructed wetland shows that the general performance of the system was good and it successfully reduced contaminants even under fluctuating contaminant loading resulting from power breakdown. The results indicate that if constructed wetlands are appropriately designed and operated, they could be used for secondary and tertiary wastewater treatment under local conditions, successfully. Hence constructed wetlands can be used in the treatment train to upgrade the existing malfunctioning wastewater treatment plants, especially in developing countries. The treated wastewater from these wetlands can be used for landscape irrigation and also for other beneficial uses.

\section{ACKNOWLEDGMENT}

The author wishes to acknowledge the support provided by Syed Wasiuddin and Mr. Niaz Hussain of Services Department, NED University of Engineering and Technology for construction of wetland.

\section{REFERENCES}

[1] J. Vymazal, "Constructed wetlands for wastewater treatment: five decades of experience," Environmental Science and Technology, vol. 45, no. 1, pp. 61-69, August 2010.

[2] R. H. Kadlec and S. Wallace, Treatment Wetlands; Boca Raton: CRC, 2009, ch. 1, ch. 6- ch. 9. 
[3] A. K. Kivaisi, "The potential for constructed wetlands for wastewater treatment and reuse in developing countries: a review," Ecological Engineering, vol. 16, no. 4, pp. 545-560, February 2001.

[4] M. Greenway, "The role of constructed wetlands in secondary effluent treatment and water reuse in subtropical and arid Australia," Ecological Engineering vol. 25, no. 1, pp. 501-509, December 2005.

[5] Standard Methods for the Examination of Water and Wastewater, 20th ed. APHA, AWWA, WEF, Washington, DC, 1998.
[6] Z. Song, Z. Zheng, J. Li, X. Sun, X. Han, W. Wang, M. Xu, "Seasonal and annual performance of a full-scale constructed wetland system for sewage treatment in China," Ecological Engineering, vol. 26, no. 3, pp. 272-282, March 2006

[7] U.S. Guidelines for Water Reuse, Environmental Protection Agency, Report No. EPA/625/R-04/108, Cincinnati, OH, USA, 2004. 